\title{
Genetic Variability and Heritability of Fodder Yield and its Contributing Traits in Rice Bean
}

\author{
A. P. Janjal ${ }^{1 *}$ and A. K. Mehta ${ }^{2}$ \\ Department of Plant Breeding and Genetics, College of Agriculture, Jawaharlal Nehru Krishi \\ Vishwa Vidyalaya, Jabalpur - 482004, Madhya Pradesh, India \\ *Corresponding author
}

\begin{tabular}{|l|}
\hline Ke y w o r d s \\
Vigna umbellate, \\
Genetic variability, \\
GCV, PCV, \\
Heritability, \\
Genetic advance \\
\hline Article Info \\
\hline $\begin{array}{l}\text { Accepted: } \\
\text { 04 November } 2019 \\
\text { Available Online: } \\
\text { 10 December } 2019\end{array}$ \\
\hline
\end{tabular}

\section{Introduction}

The rice bean (Vigna umbellata (Thunb.) Ohwi and Ohashi), a member of the leguminosae (Fabaceae) family, is an annual and self pollinated crop. It is a multipurpose and underutilized fodder legume.. It has an important role in human, animal and soil health improvement. It is a good source of protein, essential amino acids, essential fatty acids and minerals. The dried seeds make an excellent addition to cereal based diet. It is useful for livestock feeding. The vegetative parts can be feed fresh or made into hay. It is grown for green manure, as a cover crop and used as a living fence or biological barrier (Ecoport, 2014). Being a nitrogen fixing legume, it also improves the nitrogen status of 
the soil. Also, it is a lean period crop that provides subsistence to the farmers with fodder supply throughout growing season for animal population. It is best adapted to drought-prone sloping areas and flat rainfed conditions. The yield and its contributing characters of any crop are polygenetically controlled, environmentally influenced and its improvement through breeding progamme is determined by the magnitude and nature of their genetic variability and heritability (Fisher, 1981). Heritability reveals the degree to which a character is transmitted from parents to offspring. The magnitude of such estimates suggests the extent to which improvement is possible through selection. Since selection of superior genotypes is proportional to the amount of genetic variability present and the extent to which the characters are inherited, so it is necessary to obtain adequate information on the magnitude and type of genetic variability and their corresponding heritability

\section{Materials and Methods}

The experiment was conducted under All India Coordinated Research Project on forage crops, Department of Genetics \& Plant Breeding at Seed Breeding Farm, College of Agriculture, JNKVV, Jabalpur (M.P) during 2017 situated in the semi-arid sub-tropics at $23.91^{\circ}$ North latitude and $79.5^{\circ}$ East longitudes with an altitude of 411.78 meters above the mean sea level.

The experiment was conducted in Randomized Complete Block Design (RCBD) with three replications in kharif season on 47 genotypes. Each entry was planted in $3.0 \mathrm{~m} \mathrm{X}$ $0.9 \mathrm{~m}$ plot size and spacing between rows was kept $30 \mathrm{~cm}$. Observations were recorded on randomly selected five competitive plants in each plot, excluding the border plants for twenty characters viz., days to flower initiation, days to harvest, plant height $(\mathrm{cm})$, number of leaves per plant, number of branches, stem diameter $(\mathrm{mm})$, root length $(\mathrm{cm})$, root volume $(\mathrm{ml})$, number of root nodules per plant, leaf area $\left(\mathrm{cm}^{2}\right)$, fresh root weight $(\mathrm{g})$, dry root weight $(\mathrm{g})$, green fodder yield per plant $(\mathrm{g})$, green fodder yield per plant per day $(\mathrm{g})$, dry matter yield per plant (g), dry matter yield per plant per day (g), crude protein yield per plant $(\mathrm{g})$, crude protein yield per plant per day (g), leaf stem ratio and chlorophyll content index. The statistical analysis of the data on the individual trait was analysed with INDOSTAT software.

\section{Results and Discussion}

The analysis of variances of 47 rice bean genotypes for all the characters studied showed that genotypes differed significantly indicating a substantial genetic variability in the material as presented in Table 1(a) and 1(b). These are in agreement with Udensi et al., (2011) for number of leaves per plant and leaf area, Manggoel (2007) for days to harvest, Malarvizhi et al., (2005) for days to harvest, plant height, number of branches per plant, number of leaves per plant, stem thickness, dry matter yield, green fodder yield, leaf stem ratio and crude protein content, Singh et al., (1997) and Baraskar et al., (2014) for plant height. Katoch et al., (2007) for plant height and fresh fodder yield, Das et al., (1997) for days to harvest and plant height and Bandopadhyay et al., (2007) for leaf area.

The genetic parameters viz., genotypic and phenotypic coefficients of variation, heritability in broad sense and genetic advance along with mean and range of different characters are presented in Table 2.

The genotypic and phenotypic coefficients of variation were computed to assess the existing variability in the material. In general phenotypic coefficient of variation was higher than the corresponding genotypic coefficient 
of variation for almost all the traits which indicates role of environment for these characters.

\section{Genotypic coefficient of variation}

Highest GCV was observed for crude protein yield per plant per day, dry root weight, crude protein yield per plant, dry matter yield per plant per day, dry matter yield per plant, green fodder yield per plant, green fodder yield per plant per day, fresh root weight, root volume, number of root nodules per plant, number of leaves per plant and leaf stem ratio. The moderate value was recorded for root length, stem diameter, number of branches per plant and plant height. This indicates the presence of sufficient amount of genetic variability for these traits and can be exploited by breeding procedure for improvement of these characters. While, leaf area, chlorophyll content index, days to harvest and days to flower initiation had lowest values.

The results were comparable with Kohli and Agarwal (2012) and Roquib and Patnaik (1990) for green fodder yield per plant. Borah and Khan (2000) for number of leaves per plant, leaf stem ratio, dry fodder yield and green fodder yield. Nath and Tajane (2014) for green fodder yield per plant, dry matter yield per plant and branches per plant and Sharma et al., (2017) for branches per plant and plant height. Dodake and Dahat (2011) for number of number of root nodules per plant and days to harvest.

\section{Phenotypic coefficient of variation}

Dry matter yield per plant per day recorded the highest PCV followed by dry matter yield per plant, green fodder yield per plant, green fodder yield per plant per day, dry root weight, crude protein yield per plant per day, crude protein yield per plant, root volume, fresh root weight, number of root nodules per plant, number of leaves per plant, root length, stem diameter, leaf stem ratio, number of branches per plant and plant height. The moderate value of PCV was recorded for leaf area and the lowest value was observed for chlorophyll content index, days to harvest and days to flower initiation. It indicates the selection based on these characters would facilitate the successful isolation of desirable fodder type.

These results are in conformation with reports of Roquib and Patnaik (1990), Kohli and Agarwal (2012) and Kohli (2002) for green fodder yield per plant and plant height, Das et al., (1997) for plant height and Sharma et al., (2017) for number of branches per plant and plant height, Borah and Khan (2000) for number of branches per plant, number of leaves per plant, leaf stem ratio, dry fodder yield and green fodder yield, Nath and Tajane (2014) for green fodder yield per plant, dry matter yield per plant, branches per plant, Dodake and Dahat (2011) for number of number of root nodules per plant, number of branches per plant and days to harvest.

\section{Heritability and genetic advance}

Heritability estimates along with the genetic advance are normally more helpful in predicting the genetic gain under selection than heritability estimates alone. However, it is not necessary that the character showing high heritability will also exhibit high genetic advance.

High heritability with high genetic advance was exhibited by crude protein yield per plant followed by crude protein yield per plant per day, fresh root weight, dry root weight, number of leaves per plant, number of root nodules per plant, leaf stem ratio, root volume and plant height indicating lesser influence of environment in expression of these characters and preponderance of additive gene action, hence amenable for simple selection. 
Table.1(a) Analysis of variance for fodder yield and its components in Vigna umbellate

\begin{tabular}{|c|c|c|c|c|c|c|c|c|c|c|c|}
\hline \multirow{2}{*}{$\begin{array}{c}\text { Sources of } \\
\text { variation }\end{array}$} & \multirow{2}{*}{$\begin{array}{c}\text { Degree } \\
\text { of } \\
\text { freedom }\end{array}$} & \multicolumn{10}{|c|}{ Mean Sum of Squares } \\
\hline & & $\begin{array}{c}\text { Days to } \\
\text { flower } \\
\text { initiation }\end{array}$ & $\begin{array}{l}\text { Days to } \\
\text { harvest }\end{array}$ & $\begin{array}{c}\text { Plant } \\
\text { Height } \\
\text { (cm) }\end{array}$ & $\begin{array}{l}\text { No. of } \\
\text { leaves / } \\
\text { plant }\end{array}$ & $\begin{array}{l}\text { No. of } \\
\text { branches } \\
\text { / plant }\end{array}$ & $\begin{array}{c}\text { Stem } \\
\text { diameter } \\
(\mathbf{m m})\end{array}$ & $\begin{array}{c}\text { Root } \\
\text { length } \\
\text { (cm) }\end{array}$ & $\begin{array}{c}\text { Root } \\
\text { volume } \\
\text { (ml) }\end{array}$ & $\begin{array}{c}\text { No. of root } \\
\text { nodules / } \\
\text { plant }\end{array}$ & $\begin{array}{l}\text { Leaf area } \\
\qquad\left(\mathrm{cm}^{2}\right)\end{array}$ \\
\hline Replication & 2 & 93.28 & $586.64 *$ & 18.29 & 13.36 & 0.44 & 0.59 & $251.03 *$ & 6.04 & 29.04 & $2019.42 * *$ \\
\hline Treatment & 46 & $72.22 *$ & $94.73 *$ & $3071.56 * *$ & $2314.73 * *$ & $5.33 * *$ & $2.94 * *$ & $404.25 * *$ & $64.27 * *$ & $2484.06 * *$ & $531.58 * *$ \\
\hline Error & 92 & 10.58 & 15.42 & 364.33 & 168.54 & 1.02 & 0.80 & 80.40 & 7.15 & 197.26 & 185.03 \\
\hline
\end{tabular}

Table.1(b) Analysis of variance for fodder yield and its components in Vigna umbellate

\begin{tabular}{|c|c|c|c|c|c|c|c|c|c|c|c|}
\hline \multirow{2}{*}{$\begin{array}{l}\text { Sources of } \\
\text { variation }\end{array}$} & \multirow{2}{*}{$\begin{array}{c}\text { Degree } \\
\text { of } \\
\text { freedom }\end{array}$} & \multicolumn{10}{|c|}{ Mean Sum of Squares } \\
\hline & & $\begin{array}{c}\text { Fresh } \\
\text { root } \\
\text { weight } \\
(\mathrm{g})\end{array}$ & $\begin{array}{c}\text { Dry } \\
\text { root } \\
\text { weight } \\
(\mathrm{g})\end{array}$ & $\begin{array}{l}\text { Green } \\
\text { fodder } \\
\text { yield/ } \\
\text { plant/ } \\
\text { day (g) }\end{array}$ & $\begin{array}{c}\text { Dry } \\
\text { matter } \\
\text { yield/ } \\
\text { plant (g) }\end{array}$ & $\begin{array}{c}\text { Dry } \\
\text { matter } \\
\text { yield/ } \\
\text { plant/ } \\
\text { day (g) }\end{array}$ & $\begin{array}{l}\text { Leaf } \\
\text { stem } \\
\text { ratio }\end{array}$ & $\begin{array}{c}\text { Crude } \\
\text { protein } \\
\text { yield/ } \\
\text { plant }\end{array}$ & $\begin{array}{c}\text { Crude } \\
\text { protein } \\
\text { yield/ } \\
\text { plant/ day }\end{array}$ & $\begin{array}{l}\text { Chlorophyl } \\
\text { I content } \\
\text { index }\end{array}$ & $\begin{array}{c}\text { Green } \\
\text { fodder yield/ } \\
\text { plant (g) }\end{array}$ \\
\hline Replication & 2 & 0.53 & 0.10 & $0.07 *$ & 70.66 & 0.002 & 0.001 & 1.08 & 0.000083 & 20.60 & 562.31 \\
\hline Treatment & 46 & $43.77 * *$ & $9.30 * *$ & $0.95 * *$ & $1138.08 * *$ & $0.060 * *$ & $0.060 * *$ & $21.78 * *$ & $0.001271 * *$ & $11.95^{*}$ & $18434.08 * *$ \\
\hline Error & 92 & 1.54 & 0.47 & 0.20 & 266.11 & 0.012 & 0.005 & 0.45 & 0.000028 & 3.58 & 3799.00 \\
\hline
\end{tabular}

* Significant at 5\%

** Significant at $1 \%$ 


\begin{tabular}{|c|c|c|c|c|c|c|c|c|c|c|}
\hline \multirow{3}{*}{ Character } & \multirow{2}{*}{\multicolumn{2}{|c|}{ Range }} & \multirow{3}{*}{ Mean } & \multirow{2}{*}{\multicolumn{3}{|c|}{ Variance }} & \multirow[b]{3}{*}{ GCV } & \multirow[b]{3}{*}{ PCV } & \multirow{3}{*}{$\begin{array}{l}\text { Heritability } \\
\text { broad sense } \\
\quad(\%)\left(\mathbf{h}^{2}\right)\end{array}$} & \multirow{3}{*}{$\begin{array}{c}\text { Genetic } \\
\text { advance } \\
\text { as \% of } \\
\text { mean }\end{array}$} \\
\hline & & & & & & & & & & \\
\hline & Min & Max & & Phenotypic & Genotypic & Environment & & & & \\
\hline Days to flower initiation & 106.66 & 140.66 & 128.58 & 31.128 & 20.547 & 10.581 & 3.52 & 4.33 & 66.00 & 5.89 \\
\hline Days to harvest & 113.66 & 148.66 & 137.04 & 41.865 & 26.437 & 15.428 & 3.75 & 4.72 & 63.14 & 6.14 \\
\hline Plant height(cm) & 116.46 & 247.10 & 176.43 & 1266.741 & 902.410 & 364.330 & 17.02 & 20.17 & 71.23 & 29.60 \\
\hline No. of leaves/plant & 49.00 & 166.33 & 112.57 & 883.940 & 715.397 & 168.543 & 23.75 & 26.41 & 80.93 & 44.03 \\
\hline No. of branches/plant & 4.33 & 10.33 & 7.02 & 2.464 & 1.438 & 1.027 & 17.07 & 22.35 & 58.36 & 26.86 \\
\hline Stem diameter(mm) & 3.18 & 7.69 & 4.86 & 1.515 & 0.713 & 0.801 & 17.35 & 25.29 & 47.06 & 24.53 \\
\hline Root length(cm) & 33.30 & 83.96 & 53.23 & 188.355 & 107.952 & 80.403 & 19.51 & 25.77 & 57.31 & 30.43 \\
\hline Root volume(ml) & 5.33 & 28.66 & 14.17 & 26.192 & 19.041 & 7.151 & 30.77 & 36.09 & 72.69 & 54.06 \\
\hline No. of root nodules/plant & 57.72 & 186.09 & 104.73 & 959.532 & 762.269 & 197.263 & 26.36 & 29.57 & 79.44 & 48.40 \\
\hline Leaf area $\left(\mathrm{cm}^{2}\right)$ & 103.29 & 154.56 & 129.17 & 300.552 & 115.517 & 185.035 & 8.32 & 13.42 & 38.43 & 10.62 \\
\hline Fresh root weight(g) & 3.89 & 19.09 & 11.16 & 15.622 & 14.075 & 1.547 & 33.66 & 35.40 & 90.09 & 65.70 \\
\hline Dry root weight(g) & 1.01 & 7.80 & 3.64 & 3.415 & 2.943 & 0.472 & 47.01 & 50.65 & 86.17 & 89.90 \\
\hline $\begin{array}{c}\text { Green fodder } \\
\text { yield/plant/day }(g)\end{array}$ & 0.61 & 2.48 & 1.32 & 0.456 & 0.247 & 0.209 & 37.47 & 51.15 & 54.16 & 57.07 \\
\hline Dry matter yield/plant(g) & 13.99 & 83.22 & 42.52 & 556.771 & 290.659 & 266.112 & 40.08 & 55.49 & 52.20 & 59.67 \\
\hline $\begin{array}{c}\text { Dry matter } \\
\text { yield/plant/day }(g)\end{array}$ & 0.10 & 0.64 & 0.30 & 0.028 & 0.016 & 0.012 & 42.46 & 55.77 & 57.14 & 65.65 \\
\hline Leaf stem ratio & 0.45 & 1.22 & 0.65 & 0.024 & 0.018 & 0.005 & 20.77 & 23.63 & 75.00 & 37.61 \\
\hline $\begin{array}{l}\text { Crude protein } \\
\text { yield/plant(g) }\end{array}$ & 1.73 & 13.20 & 5.80 & 7.562 & 7.10 & 0.453 & 45.93 & 47.37 & 93.89 & 91.74 \\
\hline $\begin{array}{l}\text { Crude protein } \\
\text { yield/plant/day(g) }\end{array}$ & 0.01 & 0.09 & 0.04 & 0.000 & 0.00 & 0.000 & 47.60 & 49.18 & 93.70 & 94.92 \\
\hline $\begin{array}{l}\text { Chlorophyll content } \\
\text { index }\end{array}$ & 32.30 & 46.63 & 39.12 & 6.373 & 2.79 & 3.583 & 4.27 & 6.45 & 43.77 & 5.81 \\
\hline $\begin{array}{l}\text { Green fodder } \\
\text { yield/plant(g) }\end{array}$ & 88.84 & 369.05 & 181.40 & 8677.363 & 4878.360 & 3799.003 & 38.50 & 51.35 & 56.21 & 59.46 \\
\hline
\end{tabular}


The results are in close proximity with the findings of Kumar et al., (1997), Lokesh et al., (2003), Baraskar et al., (2014), Sharma et al., (2017) for plant height, Aditiya et al., (2011) for dry matter yield per plant, Singh et al., (2010) for plant height, dry matter yield and green fodder yield, Bhandari and Verma (2008) for plant height, number of leaves per plant, crude protein content and green fodder yield.

Moderate heritability with high genetic advance was exerted by green fodder yield per plant, dry matter yield per plant per day, green fodder yield per plant per day, root length, number of branches per plant and stem diameter. Whereas, leaf area exhibited low heritability with moderate genetic advance. This indicates the presence of additive gene action and selection of these characters may be rewarding.

Moderate heritability with low genetic advance was reported for days to harvest and days to flower initiation. While, low heritability with low genetic advance was observed for chlorophyll content index indicating that non-additive gene action play major role in the inheritance of these characters. Thus, the direct selection based on these characters may not be effective.

\section{References}

Aditya J P, Bhartiya P and Bhartiya A. 2011. Genetic variability, heritability and character association for yield and component characters in soybean $(G$. $\max ($ L.) Merrill). Journal of Central European Agriculture 12(1): 27-34.

Bhandari M S and Verma J S. 2008. Genetic analysis of forage yield and quality traits in cowpea [Vigna unguiculata (L.) Walp.]. Forage Research 33(4): 203-205.

Bandopadhyay P, Mazumdar D and Panja BN.
2007. Estimation of area of rice bean (Vigna umbellata) leaf by linear measurements. Forage Research 33(1): 9-12.

Baraskar V V, Kachhadia V H, Vachhani J H, Barad H R, Patel M B and Darwankar MS. 2014. Genetic variability, heritability and genetic advance in soybean (Glycine max). Electronic Journal of Plant Breeding 5(4): 802806.

Borah H K and Khan A K F. 2000. Variability, heritability and genetic advance in fodder cowpea. Madras Agricultural Journal 87(1): 75 -90.

Das M, Chattopadhyay $\mathrm{P}$ and Roguib MA. 1997. Genetic variability in grain yield and its components in rice bean [Vigna umbellate (Thumb) Ohawi and Ohashi]. Environment and Economics 15 (3): 625- 628.

Dodake M M and Dahat D V. 2011. Genotypic and phenotypic variability in rice bean. International Journal of Plant Science 6 (2): 370-371.

Ecoport, 2014. Ecoport database, http://www.ecoport.org/

Fisher RA. 1981. The correlation among relatives on the supposition of Mendelian inheritance. Transactions of the Royal Society of Edinburgh 52: 399-433.

Katoch R, Salej Sood, Naveen Kumar and Bandhari JC. 2007. Fodder production potential and nodulation efficiency of different ricebean genotypes. Forage Research 33(2): 73-77.

Kohli K S and Agarwal D K. 2012. Character association and path coefficient analysis in forage cowpea. Range Management and Agroforestry 23: 6669.

Kumar R and Sangwan R S. 2000. Genetic variability and heritability in cowpea [Vigna unguiculata (L.) Walp]. Annual Biosciences 16: 181-183. 
Lokesh, Verma P K, Gupta S N and Behl R K. 2003. Genotypic variation for important morphological characters and seed yield attributes in rice bean. Forage Research 29(4): 189-191.

Malarvizhi D, Swaminathan C, Robin S and Kannan K. 2005. Genetic variability studies in fodder cowpea. Legume Research28(1): 52-54.

Manggoel W, Uguru M I, Ndam O N and Dasbak M A. 2007. Genetic variability, correlation and path coefficient analysis of some yield components of ten cowpea [Vigna unguiculata (L.) Walp.] accessions. Journal of Plant Breeding and Crop Science 4(5): 80-86.

Nath A and Tajane P A. 2014. Genetic variability and diversity for green forage yield in cowpea [Vigna unguiculata (L.) Walp.]. International Journal of Plant Sciences 9(1) :27-30.

Roquib M A and Patnaik R K. 1990. Genetic variability in forage yield and its components in cowpea (Vigna unguiculata). Environment and Ecology 8(1): 236-238.

Sharma M, Sharma P P, Upadhyay B, Bairwa
H L and Meghawal D R. 2017. Character association and path analysis in cowpea [Vigna unguiculata (L.) Walp] germplasm line. International Journal of Current Microbiology and Applied Sciences 6(6): 786-795.

Singh M R K, Chakravarti D and Singh N B. 1997. Genetic variability, correlation and path analysis in rice bean [Vigna umbellata (Thunb) Ohwi and Ohashi] cultivars of Manipur. Indian Journal of Hill Farming 10(1/2): 23-28.

Singh S B, Singh A K and Singh A P. 2010. Genetic variability, trait relationship and path analysis for green fodder yield and its components in cowpea (Vigna unguiculata) under rainfed environment. Progressive Agriculture 10: 42-46.

Udensi O, Edu E A, Umana E J and Ikpeme E V. 2011. Estimation of genetic variability in locally grown pulses (Cajans cajan (L.) Millsp and Vigna unguiculata (L.) Walp): a panacea for sourcing superior genotypes. Pakistan Journal of Biological Sciences 14(6): 404-407.

\section{How to cite this article:}

Janjal, A. P. and Mehta, A. K. 2019. Genetic Variability and Heritability of Fodder Yield and its Contributing Traits in Rice Bean. Int.J.Curr.Microbiol.App.Sci. 8(12): 57-63. doi: https://doi.org/10.20546/ijcmas.2019.812.009 